\title{
Eosinophilic esophagitis in adults, an emerging cause of dysphagia. Description of 9 cases
}

\author{
A. J. Lucendo Villarín, G. Carrión Alonso, M. Navarro Sánchez¹, S. Martín Chavarri, S. Gómez Senent, \\ P. Castillo Grau, J. M. Pascual Turrión and P. González Sanz-Agero
}

Services of Digestive Diseases and 'Pathology. Hospital Universitario La Paz. Madrid, Spain

\begin{abstract}
Background: eosinophilic esophagitis is a rare condition mainly affecting children, although the number of cases reported in adults is on the increase. It is characterized by intense infiltration of eosinophilic leukocytes in the esophageal mucosa, without involvement of other sections of the alimentary canal.

Material and methods: over the past year, following the performance of endoscopies and biopsies, our service identified nine patients who were diagnosed with suffering from this disorder. Each patient sought medical help for episodes of long-term, self-limited dysphagia or food impaction in the alimentary canal.

Results: endoscopy revealed esophageal stenosis in the form of simultaneous contraction rings or regular stenosis. In six cases, the manometric study showed a nonspecific motor disorder of severe intensity affecting the esophageal body, and another patient had a disorder characterized by the presence of simultaneous waves and secondary peristaltic waves in the three thirds of the organ. These disorders are presumably due to eosinophilic infiltration of the muscular layer or ganglionar cells of the esophagus, and account for symptoms in these patients. Although the etiopathogenesis of this illness is uncertain, it is clearly an immunoallergic manifestation.

Conclusions: as the number of diagnosed cases is on the increase, eosinophilic esophagitis is in adults a specific entity within the differential diagnosis of dysphagia in young males with a history of allergies. Eosiniphilic esophagitis responds in a different number of ways to therapies used. We successfully used fluticasone propionate, a synthetic corticoid applied topically, which proved to be efficient in the treatment of this illness by acting on the pathophysiological basis of the process. It does not have any adverse effects, thus offering advantages over other therapies such as systematic corticoids or endoscopic dilations.
\end{abstract}

Key words: Esoinophilic esophagitis. Allergic esophagitis. Dysphagia. Esophageal motor disorder. Esophageal stenosis. Young adults. Food impactation.

Recibido: 26-05-04.

Aceptado: 19-10-04.

Correspondencia: Alfredo José Lucendo Villarín. C/ Carnicer, 22, $3^{\circ}$ B. 28039 Madrid. Tel.: 617885 975. e-mail: alucendo@vodafone.es
Lucendo Villarín AJ, Carrión Alonso G, Navarro Sánchez M, Martín Chavarri S, Gómez Senent S, Castillo Grau P, Pascual Turrión JM, González Sanz-Agero P. Eosinophilic esophagitis in adults, an emerging cause of dysphagia. Description of 9 cases. Rev Esp Enferm Dig 2005; 97: 229-239.

\section{INTRODUCTION}

Eosinophilic esophagitis (EE) is a rare clinico-pathological disorder characterized by an infiltration of eosinophilic leukocytes in the esophageal mucous membrane, not involving other sections of the alimentary canal. Although it can be clearly differentiated from eosinophilic gastroenteritis (EG) $(1,2)$, this esophageal condition may be present in up to $50 \%$ of cases with this illness (3). It predominantly affects males who very often show manifestations of hypersensitivity to airborne allergens and/or certain components of the diet, and a variable proportion (up to $83 \%$ or those in the children's form) (4) have symptoms of blood eosinophilia. Although the disorder is more common during childhood, it is becoming increasingly diagnosed in adults. In our study, we analyze the cases we diagnosed during the course of our practice over the past year.

\section{PATIENTS AND METHODS}

Between May 2003 and May 2004 our department treated 9 patients clinically diagnosed with dysphagia or food impaction, which were consequently referred to the Endoscopy Unit. After upper gastrointestinal endoscopy and biopsy collection from the upper and lower thirds of the esophagus, eosinophilic esophagitis was diagnosed due to the presence of more than 24 eosinophilic leukocytes per high-power field (5). Other sections of the ali- 
mentary canal remained unaffected after the stomach and/or duodenal biopsies were performed. After carrying out a 24-hour esophageal pH-metry and studying the presence of gastroesophageal reflux, the patients who had it were treated with omeprazole (40 $\mathrm{mg} /$ day) for two months before biopsies were repeated, thereby ruling it out as the cause for eosinophilic esophagitis (6). Endoscopic findings and motor disorders linked to this illness were recorded using stationary esophageal manometry, carried out with a pneumohydraulic perfusion system. Although all nine patients showed a certain history of allergies, neither this criteria nor the presence of blood hypereosinophilia were taken into consideration during the diagnosis. Consent was given by all patients or their tutors prior to the carrying out of examinations.

\section{RESULTS}

All of our patients were young, aged between 15 and 38 years, and comprised eight men and one woman with a long-term history of allergies, mainly allergic asthma and seasonal rhinoconjunctivitis caused by dust mites, pollen and food. Three patients had slightly high levels of eosinophils in their blood.

The first endoscopic examination showed a concentric stenosis, which prevented observation of the distal lumen in three patients. The other six patients had simultaneous contraction rings along the length of the esophagus, which in two cases obstructed the passage of the endoscope while permitting observation of the esophageal lumen (Figs. 1-3). Three patients showed a slight alteration of the esophageal mucosa.

The manometric study revealed an abnormal behavior of the upper esophageal sphincter in two cases. Seven patients were shown to suffer from esophageal motor disorders. Six patients had a severe, non-specific, esophageal motor disorder, while the remainder had an alteration of the esophageal motor dynamics characterized by $80 \%$ of deglutitive complexes being formed by a primary simultaneous wave in the 2 lower thirds of the esophagus, followed, in $50 \%$ of cases, by a secondary peristaltic wave (Fig. 4), The behavior of the lower esophageal sphincter was variable and showed hardly any correlation with the results of esophageal pH-metry.

Four patients showed pathological gastroesophageal reflux during 24-hour $\mathrm{pH}$ monitoring. None showed signs of clinical improvement or remission of their esophageal eosinophilia following treatment with proton pump inhibitors.

Table I shows the patients' clinical characteristics and the findings from tests.

In each case, esophageal biopsies detected a mucosa with moderate acanthosis, papillomatosis, and basal cell hyperplasia with outstanding inflammatory infiltration by predominantly eosinophils, with more than 24 per highpower field. This infiltrate was mainly located in the mid- dle and superficial section of the epithelium (Fig. 5). None of the patients had eosinophilic infiltration in the samples taken from the stomach or duodenum.

Seven patients required treatment: in five cases, a topical steroid was used (fluticasone propionate, $500 \mu \mathrm{g} / 12$ hours for 3 months), in one patient, after an endoscopic dilation had proved unsuccessful. One patient received methylprednisolone $(0.5 \mathrm{mg} / \mathrm{kg}$ weight/day over a 6month period, which was gradually reduced). In all cases treated, symptomatic improvement was observed from the second week of treatment onwards. Once treatment was completed, another upper endoscopic examination was performed, which produced no pathological findings. The esophageal biopsies obtained from this procedure were reported to be normal. Endoscopic dilation was carried out on one patient who currently remains asymptomatic. Although two patients did not require specific treatment, they received antisecretory medication for a short period.

\section{DISCUSSION}

Eosinophilic esophagitis is a rare entity. Since first identified (7), only 200 cases have been documented, $35 \%$ of which being described as having occurred in adults (8). Traditionally considered to have been a childhood disorder, we are currently witnessing an obvious increase in the number of cases diagnosed and reported; although the incidence of the illness is unknown, it could be on the rise. Less is known regarding the manifestation of EE in adults, and EE is usually not included in the differential diagnosis of dysphagia. It predominantly affects young males in their thirties and forties, which in a high proportion of cases have atopical manifestations, which are probably related to the immunoallergic etiology of the process. EG is different to EE in that it appears earlier and the stomach and small intestine are infiltrated by an abundance of eosinophilic leukocytes in almost every patient; in up to $50 \%$ of cases, esophageal infiltration is reported. Its progression is that of an intestinal illness (abdominal colic pain, diarrhea, poor absorption, and weight loss) (2), with symptoms not shown by our patients.

The general increase in allergic illnesses and atopical manifestations is also becoming increasingly linked to EE. According to several authors, its incidence and prevalence could be on the rise. This reinforces the etiological assumption that it is the organ's reaction to dietary components or air-borne allergens, which forces us to consider the esophagus as an immunologically active organ capable of being involved in allergic reactions, and not simply as a tube leading to the stomach. However, it is argued whether the stimulus in question acts locally or systemically on the esophagus $(6,9)$, since allergic esophagitis is the only manifestation of hypersensitivity in a small number of cases. On the other hand, blood eosinophilia expresses the systemic nature of the process. 
Table I. Characteristics of esoinophilic esophagitis cases

\begin{tabular}{|c|c|c|c|c|c|c|c|c|c|c|c|c|}
\hline & \multirow{2}{*}{$\begin{array}{l}\text { Age (years) } \\
\text { and sex }\end{array}$} & \multirow{2}{*}{$\begin{array}{l}\text { Manifestations } \\
\text { of allergies }\end{array}$} & \multirow{2}{*}{$\begin{array}{l}\text { Type of } \\
\text { allergen }\end{array}$} & \multirow{2}{*}{$\begin{array}{l}\text { Blood } \\
\text { eosinophilia }\end{array}$} & \multirow{2}{*}{$\begin{array}{l}\text { Specific lg } E \\
\text { increase }\end{array}$} & \multirow{2}{*}{$\begin{array}{l}\text { Endoscopy performed } \\
\text { upon diagnosis }\end{array}$} & \multicolumn{3}{|c|}{ Manometry } & \multirow{2}{*}{$\begin{array}{l}\text { 24-hour } \\
\text { pH metry }\end{array}$} & \multirow[t]{2}{*}{ Treatment } & \multirow{2}{*}{$\begin{array}{l}\text { Response to } \\
\text { treatment }\end{array}$} \\
\hline & & & & & & & UES & $\begin{array}{l}\text { Esophageal } \\
\text { body }\end{array}$ & LES & & & \\
\hline Case 1 & 15 , male & $\begin{array}{l}\text { Seasonal } \\
\text { asthma }\end{array}$ & $\begin{array}{l}\text { Dust mites, } \\
\text { pollen }\end{array}$ & No & No & $\begin{array}{l}\text { Concentric } \\
\text { stenosis }\end{array}$ & Normal & Aperistalsis & Normal & $\begin{array}{l}\text { Pathological, } \\
\text { moderate and } \\
\text { mixed GER }\end{array}$ & $\begin{array}{l}\text { Endoscopic } \\
\text { dilation. } \\
\text { Topical } \\
\text { corticoids }\end{array}$ & $\begin{array}{l}\text { Clinical } \\
\text { improvement }\end{array}$ \\
\hline Case 2 & 17, male & Asthma & Food, pollen & Yes $(7 \%)$ & Yes & $\begin{array}{l}\text { Ringed oesophagus, } \\
\text { absence of stenosis. } \\
\text { Corrugation }\end{array}$ & Normal & Aperistalsis & Normal & $\begin{array}{l}\text { Non- } \\
\text { pathological } \\
\text { GER }\end{array}$ & $\begin{array}{l}\text { Topical } \\
\text { corticoids }\end{array}$ & $\begin{array}{l}\text { Clinical and } \\
\text { histological } \\
\text { improvement }\end{array}$ \\
\hline Case 3 & 18, female & $\begin{array}{l}\text { Dermatitis, } \\
\text { asthma, } \\
\text { angioedema } \\
\text { anaphylaxia }\end{array}$ & Food, pollen & Yes $(9 \%)$ & Yes & $\begin{array}{l}\text { Ringed } \\
\text { oesophagus, } \\
\text { absence of } \\
\text { stenosis }\end{array}$ & $\begin{array}{l}\text { Normotense, } \\
\text { with certain } \\
\text { signs of } \\
\text { incomplete } \\
\text { relaxation }\end{array}$ & $\begin{array}{l}20 \% \text { normal } \\
\text { peristaltic } \\
\text { waves. } 80 \% \\
\text { deglutory } \\
\text { activity with } \\
\text { simultaneous } \\
\text { waves and } \\
\text { secondary } \\
\text { peristalsis }\end{array}$ & Normal & $\begin{array}{l}\text { Very slight } \\
\text { pathological } \\
\text { GER }\end{array}$ & $\begin{array}{l}\text { Topical } \\
\text { corticoids }\end{array}$ & $\begin{array}{l}\text { Clinical and } \\
\text { histological } \\
\text { improvement }\end{array}$ \\
\hline Case 4 & 22 , male & Dermatitis & Food & No & $N / A$ & $\begin{array}{l}\text { Ringed oesophagus, } \\
\text { absence of stenosis }\end{array}$ & Normal & $\begin{array}{l}\text { Non-severe } \\
\text { hypoperistalsis }\end{array}$ & $\begin{array}{l}\text { Hypotense } \\
\text { with signs } \\
\text { of irritation }\end{array}$ & $\begin{array}{l}\text { Non- } \\
\text { pathological } \\
\text { GER }\end{array}$ & PPI & Asymptomatic \\
\hline Case 5 & 25 , male & Asthma, urticaria & Food & Yes (10\%) & Yes & $\begin{array}{l}\text { Stenosant ringed } \\
\text { oesophagus. } \\
\text { Dull mucosa }\end{array}$ & Normal & Aperistalsis & Normal & $\begin{array}{l}\text { Absence of } \\
\text { pathological } \\
\text { GER }\end{array}$ & $\begin{array}{l}\text { Topical } \\
\text { corticoids }\end{array}$ & $\begin{array}{l}\text { Clinical and } \\
\text { histological } \\
\text { improvement }\end{array}$ \\
\hline Case 6 & 28 , male & $\begin{array}{l}\text { Rhino- } \\
\text { conjunctivitis }\end{array}$ & $\begin{array}{l}\text { Dust mites, } \\
\text { pollen }\end{array}$ & No & $N / A$ & $\begin{array}{l}\text { Ringed oesophagus, } \\
\text { absence of } \\
\text { stenosis }\end{array}$ & Normal & Aperistalsis & $\begin{array}{l}\text { Normotense } \\
\text { with signs } \\
\text { of irritation }\end{array}$ & $N / A$ & PPI & Asymptomatic \\
\hline Case 7 & 29 , male & $\begin{array}{l}\text { Rhino- } \\
\text { conjunctivitis }\end{array}$ & $\begin{array}{l}\text { Dust mites, } \\
\text { pollen }\end{array}$ & No & $N / A$ & $\begin{array}{l}\text { Concentric } \\
\text { stenosis }\end{array}$ & Normal & Normal & Normal & $\begin{array}{l}\text { Non- } \\
\text { pathological } \\
\text { GER }\end{array}$ & $\begin{array}{l}\text { Topical } \\
\text { corticoids }\end{array}$ & $\begin{array}{l}\text { Clinical and } \\
\text { histological } \\
\text { improvement }\end{array}$ \\
\hline Case 8 & 35 , male & $\begin{array}{l}\text { Rhinoconjuncti- } \\
\text { vitis, asthma, } \\
\text { dermatitis }\end{array}$ & Food, pollen & No & Yes & $\begin{array}{l}\text { Concentric } \\
\text { stenosis }\end{array}$ & $\begin{array}{l}\text { Hypertense } \\
\text { with complete } \\
\text { relaxation }\end{array}$ & Aperistalsis & $\begin{array}{c}\text { Normotense, } \\
\text { with certain } \\
\text { incomplete } \\
\text { relaxation }\end{array}$ & $\begin{array}{l}\text { Slight and } \\
\text { mixed } \\
\text { pathological } \\
\text { GER }\end{array}$ & $\begin{array}{l}\text { Oral } \\
\text { corticoids }\end{array}$ & $\begin{array}{l}\text { Clinical and } \\
\text { histological } \\
\text { improvement }\end{array}$ \\
\hline Case 9 & 38 , male & $\begin{array}{l}\text { Rhino- } \\
\text { conjunctivitis }\end{array}$ & Pollen & No & $N / A$ & $\begin{array}{l}\text { Ringed oesophagus } \\
\text { with stenosis, } \\
\text { granular mucosa }\end{array}$ & Normal & Normal & $\begin{array}{l}\text { Slightly } \\
\text { hypotense } \\
\text { with } \\
\text { complete } \\
\text { relaxation }\end{array}$ & $\begin{array}{l}\text { Moderate } \\
\text { pathological } \\
\text { GER }\end{array}$ & $\begin{array}{l}\text { Endoscopic } \\
\text { dillation }\end{array}$ & Asymptomatic \\
\hline
\end{tabular}

UES: upper esophageal sphincter. LES: lower esophageal sphincter. GER: gastroesophageal reflux. PBI: proton pump inhibitors. N/A: not available.

Nevertheless, it has been highlighted the different geographical distribution of allergic asthma and EE, which suggests that other factors should be considered to supplement the theory of hyperactivity against diet or airborne allergens (9).

All of our patients were young, aged between 15 and 38 years, and predominantly males, with a history of long-term intermittent dysphagia and occasional episodes of food impaction. In each case, the endoscopy was per- formed to study dysphagia or food impaction requiring the performance of an emergency endoscopy. Two patients were referred from the allergy unit due to the presence of intermittent dysphagia, who had not been previously suspected as suffering from EE. Based on the experience gained by our department during the recently diagnosed cases of EE, we carried out biopsies during our study of patients with dysphagia where endoscopy had proved to be inconclusive. 


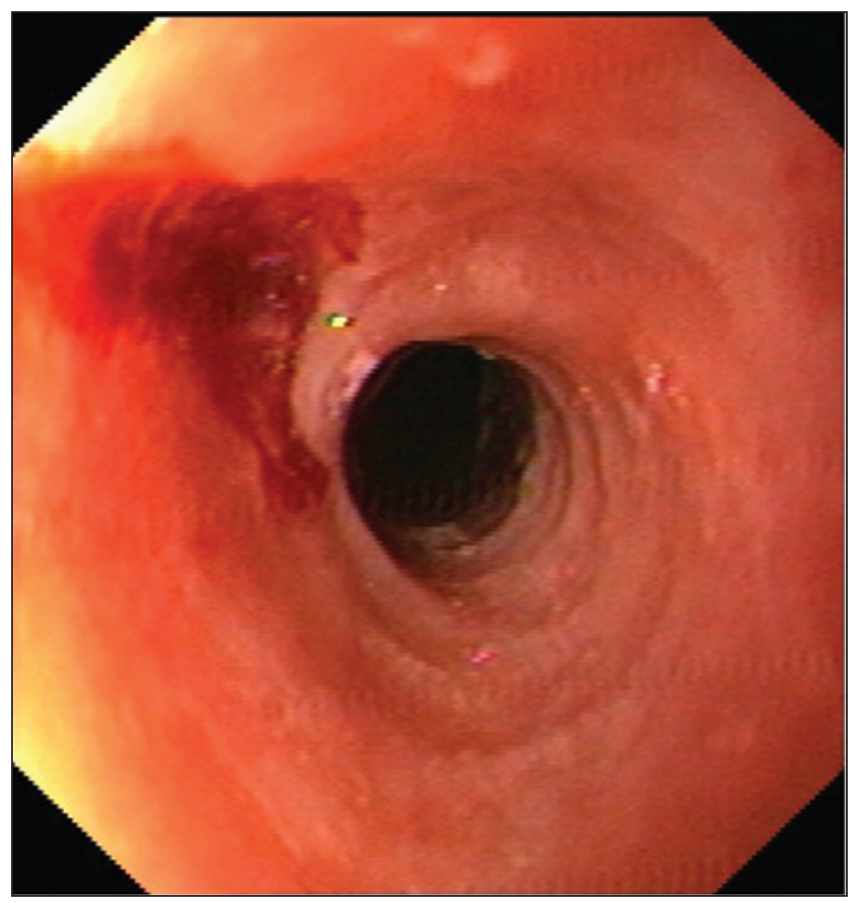

Fig. 1. Endoscopic image corresponding to case 7, who sought medical help due to meat impactation with deep erosion on the concentric stenosis of the middle third section of the oesophagus, obstructing the passage of the endoscope. The stenosis biopsy was deferred due to potential complications deriving from the deep erosion.

Imagen endoscópica correspondiente al caso 7, que consultó por impactación cárnica con erosión profunda sobre estenosis concéntrica de tercio medio esofágico que no permitía el paso del endoscopio. La toma de biopsias de la estenosis fue diferida por la potencial complicación de la erosión profunda.

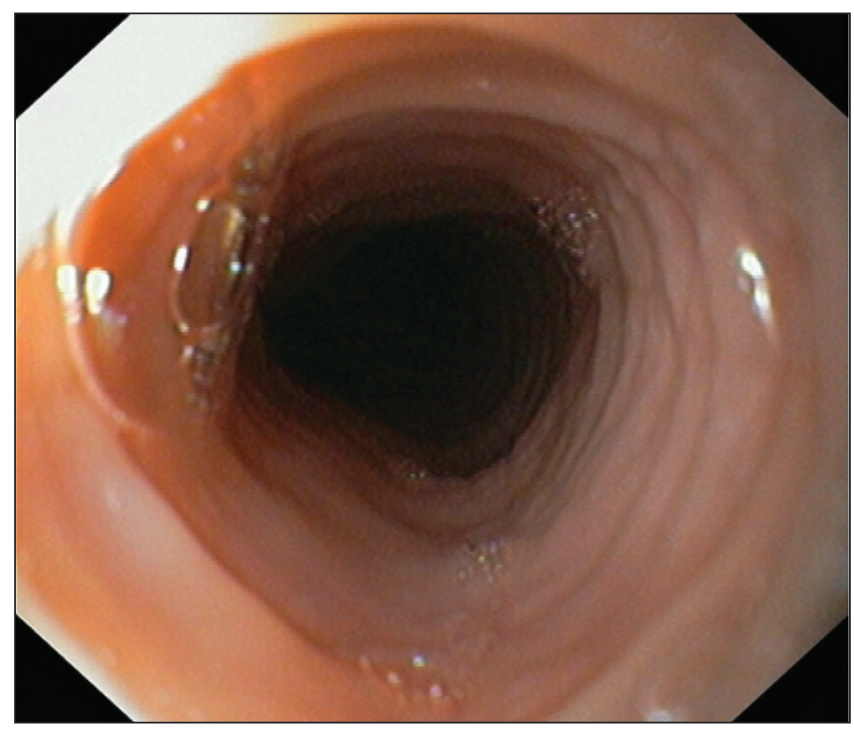

Fig. 2. Endoscopic image of the same patient (case 7) three weeks later, which shows non-stenosant primary concentric rings in the middle third of the oesophagus. No treatment was administered between the taking of both photographs.

Imagen endoscópica del mismo paciente (caso 7) tres semanas después, que muestra anillos concéntricos primarios, no estenosantes, en tercio medio esofágico. Entre ambas fotos no media tratamiento alguno.

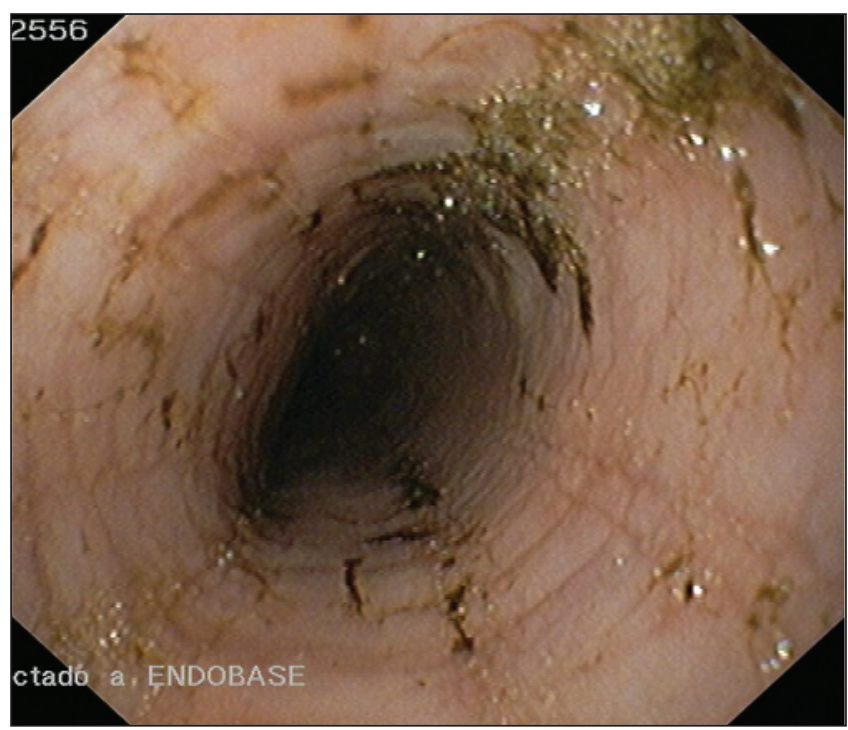

Fig. 3. Endoscopic image corresponding to case 3, showing longtitudinal furrows or mucous corrugation.

Imagen endoscópica correspondiente al caso 3, mostrando surcos longitudinales o corrugación mucosa.

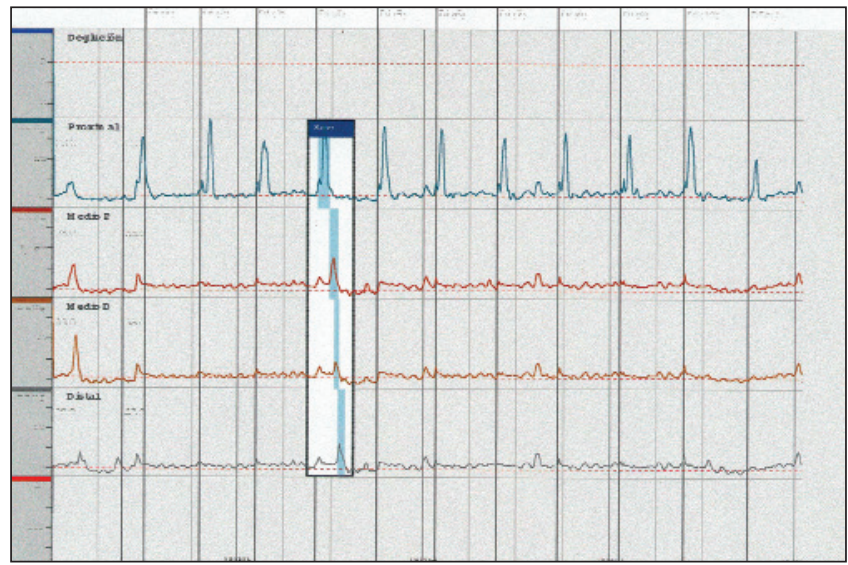

Fig. 4. Manometric study of the esophageal body, corresponding to case 1 , which shows a severe motor disorder with almost complete aperistalsis. The marked wave is the only one which is peristaltic but with low amplitude.

Registro manométrico del cuerpo esofágico, correspondiente al caso 1 , que muestra un trastorno motor severo, con aperistalsis casi competa. La onda remarcada es la única peristática, pero de baja amplitud.

All cases displayed allergic manifestations that had been generally present since childhood. Apart from dysphagia, they may also have vomiting, regurgitations or retroesternal pain $(4,6,8)$. Dysphagia is resistant to treatment with prokinetics and gastric acid secretion inhibitors, and tends to progress in an oscillating manner with asymptomatic periods followed by episodes of deterioration.

The endoscopic findings from the first exploration performed on our patients revealed two different patterns: 


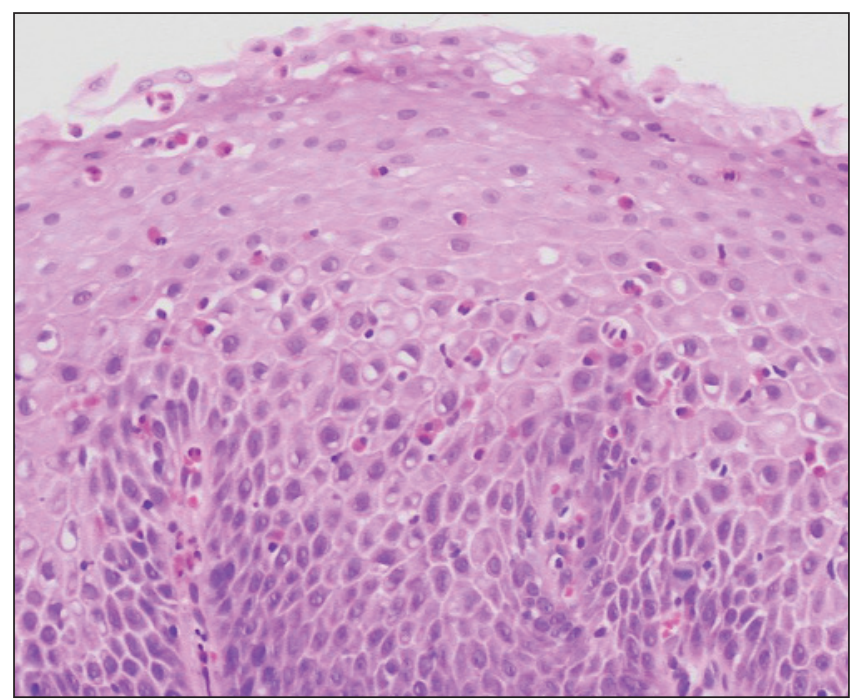

Fig. 5. Esophageal mucosa infiltrated by eosinophilic leukocytes exceeding 24/HPF. H-E, x200 (orig. mag.).

Mucosa esofágica infiltrada por leucocitos eosinófilos en número mayor de 24/HPF. H-E, x200 (orig. mag).

concentric stenosis, which hinders observation of the distal mucosa, and simultaneous concentric rings allowing observation of the esophageal lumen. However, occasionally, these rings block the passage of the endoscope, thus producing "paradoxical stenosis". Many other endoscopic patterns have been documented, such as: focal stenosis, particularly in the proximal esophagus; long segmentary stenosis or slight alterations of the mucosa affecting the full length of the organ (such as a granulartype mucosa); loss of the normal vascular pattern, longitudinal linear furrows, corrugation or white exudations spots or papulae leading to the deposition of microabscesses formed by eosinophils in the mucosa $(6,8)$. In subsequent endoscopic examinations, some patients had different results to those shown initially, which means that endoscopic findings may vary intraindividually throughout evolution.

The presence of eosinophils in the squamous epithelium of the esophagus or in the underlying layers has been described in patients with eosinophic gastroenteritis, parasite illnesses, and particularly with gastroesophageal reflux (GER) (10). GER is the main cause of esophageal eosinophilic infiltration, but is characterized by a small number of cells (generally less than 10 eosinophils per high-power field) located in the distal third of the organ. Although none of our patients showed clinical symptoms of GER or endoscopic peptic lesions, a 24-hour $\mathrm{pH}$ monitoring detected moderate pathological reflux in 4 cases. These patients still had an infiltrate of more than 24 eosinophils per high-power field in both thirds of the esophagus following treatment with antisecretory drugs, which rules out reflux as the cause of infiltration. In fact, the presence of gastroesophageal reflux has been de- scribed in EE as an unspecific result of the motor disorder deriving from organ inflammation.

After performing a manometric study, 6 of 9 patients were documented as having a moderate to severe unspecific esophageal motor disorder characterized by aperistalsis or a severe peristalsis deficiency, with very low amplitude or non-transmitting waves. One patient had a singular esophageal motor disorder characterized by having $80 \%$ of deglutitive complexes formed by a first simultaneous wave in the 2 lower thirds of the esophagus, followed by a secondary peristaltic wave in $50 \%$ of cases, which had a normal duration and amplitude. Only $20 \%$ of deglutitive complexes produced normal peristalsis. These manometric alterations may be related to the inflammation of the esophageal muscular layers or the myenteric plexus and are the cause of the clinical manifestations and endoscopic motor alterations observed in EE. Landres et al. described the case of one patient diagnosed with EG in association with an esophageal condition in which the histopathological study also showed eosinophilic infiltration of the esophageal muscular layers (11), which suggests that esophageal manifestations are due to muscular infiltration. Confirmation of this fact poses clear difficulties, but, after performing endoscopic ultrasonography in EE, a thickening of the esophageal mucosa and submucosa was observed (12), in addition to the muscular tissue itself (13), which also could reflect an increase in muscle tone.

Diverse treatments have been tested for EE, aimed at eliminating the causal antigenic stimulus or the organ's immunological response. In each case it is recommended that a sensitivity study to dietary and environment components be performed in order to avoid or control exposure. There is wide experience on the use of restrictive or elementary diets in children, which have achieved positive results $(8,14,15)$; however, in our opinion, these measures are also difficult to apply in adults, as it is a chronic pathology requiring ongoing therapy. Endoscopic dilations provide temporary relief from symptoms and have been proposed as the treatment of choice by some authors (16), but, in our opinion, it is not an advisable treatment as it causes patient discomfort and does nothing to resolve the inflammatory substrate of the process. Cellular immune hyperreactivity underlying EE has permitted the use of steroidal therapy. Corticoids have shown a remission of esophageal infiltration that is associated with symptomatic improvement $(3,8,15)$. The systemic administration of $0.5 \mathrm{mg} / \mathrm{kg}$ of methylprednisolone/day during a period of 6 months, the dosage of which is gradually reduced, achieves prolonged improvement of clinical and endoscopic manifestations (4). Fluticasone propionate, a non-absorbable synthetic corticoid applied on the tongue and subsequently swallowed, has shown results similar to systemic corticoids both in the children's $(15)$ and adult $(10,17)$ forms of EE with no adverse effects. Consequently, based on our experience and ratifying the aforementioned observations, we currently 
consider this to be the treatment of choice. Isolated cases of EG have been recently reported, which have responded to drugs modifying $\mathrm{T}_{\mathrm{H}} 2$ lymphocyte-dependent inflammation, such as sodium cromoglycate $(18,19)$, suplatast tosilate (20) or montelukast (21), the latter having been recently employed in a small group of patients diagnosed with EE $(22,23)$. Although there are many controlled studies which demonstrate the efficiency of these drugs in the treatment of corticoid-dependent asthma, in our opinion the scarce and isolated number of reported cases does not justify their use as a treatment for eosinophils of the alimentary canal.

The authors consider that primary EE should be considered in the differential diagnosis in young patients with a history of allergies and esophageal symptoms, and that endoscopy and biopsy should be performed at different levels even in the absence of lesions or in the presence of slight or intermittent symptoms. A history of allergies, in many cases since childhood, and the long symptomatic period preceding diagnosis raises the assumption that adult-onset EE may in fact consist of mild symptomatic, late-diagnosis forms of the childhood variety. Its long evolution leads to fibrosis and esophageal stenosis in adults when left untreated (6), and it should be considered as an emerging cause of dysphagia, given its growing incidence. Knowledge of the illness and its potential diagnosis should allow identifying a larger number of cases, leading to studies that may improve our knowledge on this new and enthralling illness.

\section{ACKNOWLEDGEMENTS}

The authors wish to express their gratitude to Dr. José Carlos Erdozaín Sosa for his review of the text and providing his comments.

\section{REFERENCES}

1. Attwood S, Smyrk TC, Demeester TR, et al. Esophageal eosinophilia with dysphagia. A distinct clinicopathologic syndrome. Digest Dis Sci 1993; 38: 109-16.

2. Markowitz JE, Liacouras CA. Eosinophilic esophagitis. Gastroenterol Clin N Am 2003; 32: 949-66.

3. Bory F, Vázquez E, Forcada P, et al. Esofagitis eosinofílica como causa de disfagia de 10 años de evolución. Gastroenterol Hepatol 1998; 21: 287-8

4. Borda F, Jiménez FJ, Martínez peñuela JM, Echarri A, Martín Granizo I, Álvarez R. Eosinophilic esophagitis: an underdiagnosed entity? Rev Esp Enferm Dig 1996; 88: 701-4

5. Rothenberg ME. Pathogenesis and clinical features of eosinophilic esophagitis. J. Allergy Clin Inmunol 2001; 108: 891-4.

6. Furuta GT. Clinicopathologic features of esophagitis in children. Gastrointestinal Endosc Clin N Am 2001; 11: 683-715.

7. Dobbinss JW. Eosinophilic gastroenteritis with esophageal involvement. Gastroenterology 1977; 72: 1312.

8. Fox V, Nurko S, Furuta G. Eosinophilic esophagitis: it's not just kid's stuff. Gastrointest Endosc 2002; 56: 260-70.

9. Bishop WP, Haber BA, Lichtman SN, Shneider BL. Learning more about eosinophilic esophagitis. J Pediat Gastroenterol Nutr 2002; 35: 711-2.

10. Arora AS, Perrault J, Smyrk TC. Topical corticosteoid treatment of disphagia due to eosinophilic esophagitis in adults. Mayo Clin Proc 2003; 78: 830-5.

11. Landres R, Kuster G, Strum W. Eosinophilic esophagitis in a patient with vigorous achalasia. Gastroenterology 1978; 74: 1298-301.

12. Fox VL, Nurko S, Teitelbaum JE, Badizadegan K, Furuta GT. Highresolution EUS in children with eosinophilic "allergic" esophagitis. Gastrointest Endosc 2003; 57: 30-6.

13. Fox V, Nurko S, Teitelbaum J, Furuta G. Abnormalities of the esophageal wall detected by high-resolution probe endosonography in patient with allergic esophagitis [abstract]. J Pediatr Gastroenterol Nutr 2000; 31: S282.

14. Kelly KJ, Lazenby AJ, Rowe PC, Yardley JH, Perman JA, Sampson HA. Eosinophilic esophagitis attributed to gastroesophageal reflux: improvement with an amino acid-based formula. Gastroenterology 1995; 109: 1503-12.

15. Teitelbaum J, Fox V, Twarog F, Nurko S, Antonioli D, Gleich G, et al. Eosinophilic esophagitis in children: inmunopathological analysis and response to fluticasone propionate. Gastroenterology 2002; 122: 1216-25.

16. Straumann A, Spichtin HP, Grize L, Bucher KA, Beglinger C, Simon HU. Natural history of primary eosinophilic esophagitis: a follow-up of 30 adult patients for up to 11.5 years. Gastroenterology 2003; 125 : 1660-9.

17. Langdon DE. Fluticasone in eosinophilic corrugated ringed esophagus. Am J Gastroenterol 2001; 96: 926-7.

18. Moots RJ, Prouse P, Gumpel JM. Near fatal eosinophilic gastroenteritis responding to oral sodium cromoplycate. Gut 1988; 29: 1282-5.

19. Businco L, Cantani A. Food allergy in children: diagnosis and treatment with sodium cromiglycate. Allergol Inmunopathol (Madr) 1990; 18: 339-48.

20. Shirai T, Hashimoto D, Suzuki K, Osawa S, Aonahata M, Chida K, et al. Succesful treatment of eosinophilic gastroenteritis with suplatast tosilate [letter]. J Allergy Clin Inmunol 2001; 107: 924-5.

21. Neustrom MR, Friesen C. Treatment of eosinophilic gastroenteritis with montelukast [letter]. J Allergy Clin Inmunol 1999; 104: 506.

22. Attwood SE, Lewis CJ, Bronder CS, Morris CD, Armstrong GR, Whittam J. Eosinophilic oesophagitis: a novel treatment using Montelukast. Gut 2003; 52: 181-5.

23. Sinharay R. Eosinophilic oesophagitis: treatment using Montelukast. Gut 2003; 52 (8): 1228-9. 